\title{
Die kanon in die kanon as hermeneuties-teologiese probleem
}

\author{
GMM Pelser
}

\begin{abstract}
The canon within the canon as hermeneutical-theological problem

Taking as point of departure the diversity, and in many cases the disparity of the canon, this essay agrees with a number of prominent scholars that the canon itself invites and requires priorities and preferences, and consequently its own reduction. It also points out that as a result of this fact and due to hermeneutical and theological presuppositions, theological and ecclesiastical traditions have in practice always operated with some kind of 'canon within the canon'. In view of this the conclusion arrived at, is that when one takes the canon and its problems seriously and perceives it responsibly, one has in principle no other option than to work with a canon within the canon. Although a stance like this has its problems and difficulties and runs the risk of onesidedness and the absolutizing of a particular appropriation, it is self-evidently the most preferable and can and should be effectively checked by the criticism of theological discussion.
\end{abstract}

\section{DIE VERSKEIDENHEID EN UITEENLOPENDHEID VAN DIE KANON}

Pluralism is a part of responsible perception of the concept of canon (Sanders 1984: 15).

Das Neue Testament hat sich immer stärker als eine höchst komplexe Grösse erwiesen, zum Teil als complexio oppositorum, in der ein Teil den anderen desavouiert, ja geradezu entkanonisiert (Schrage 1976: 416).

Bogenoemde stellings gee onderskeidelik uitdrukking aan enersyds 'n feit wat alleen nog in uiters konserwatiewe kringe ontken sal. word, andersyds ' $n$ oortuiging wat, hoewel dit vir baie ore radikaal mag klink, nogtans nie bestry kan word nie. ' $n$ Feit wat naamlik nie ontken kan word nie, is dat daar in die Bybel 'n verskeidenheid van teologiese 
standpunte, of dan teologieë, sowel as ontwikkelinge in hierdie teologieë aan te dui is. Hierdie verskeidenheid sou natuurlik hermeneuties en teologies geen probleem skep indien aanvaar kon word dat hulle almal legitieme en met mekaar versoenbare of harmoniseerbare uitdrukkings van dieselfde saak is nie (so bv Neill 1966: $189 \mathrm{v}$; Lohse 1982: 12). Dit skep ook nie 'n probleem vir diegene wat meen dat al die geskrifte en hulle teologieë uiteindelik as gelykwaardig kanoniek beskou kan word omdat hulle nou eenmaal deur die kerk in die kanon opgeneem is nie (so bv Childs 1984: $41 \mathrm{vv;}$ Ohlig 1972: $312 \mathrm{vv}$ ).

Dat hierdie verskeidenheid, wat die Nuwe Testament betref, in ' $n$ aantal gevalle as legitieme uitdrukkings van die Jesus-saak beskryf kan word of aan situasiebepaaldheid toegeskryf moet word, hoef nie ontken te word nie. Ons het in die Nuwe Testament beslis met sulke situasiebepaalde paradokse te doen (so tereg Joest 1970: 277). In hierdie gevalle sou dit dus minstens tot op sekere hoogte moontlik wees om te harmoniseer. Maar selfs in hierdie gevalle mag daar nie oorhaastig geharmoniseer word nie. 'n Mens loop naamlik die gevaar om deur harmonisering die kontoere van die verskillende teologiese konsepte deureen te laat loop of te nivelleer. So word die historiese karakter van die Nuwe Testament ontken en word die faktiese afgeslotenheid van die kanon tot 'n prinsipiële gemaak. Dan laat ons die Bybel nie toe om homself te interpreteer nie. Ons kan nie sonder meer werk met 'n eenheidsprinsipe waardeur alle uitsprake van die Bybel op 'n gemeenskaplike noemer teruggevoer word nie. Ons kan ook nie al die geskrifte aan die hand van een hermeneutiese prinsipe uitlê nie (kyk Diem 1970: 171). Hierbenewens is daar natuurlik nog die gewigtige probleem om uit te maak volgens watter kriterium daar vasgestel kan word dat die verskeidenheid wel legitieme uitdrukkings van dieselfde saak is. Hierop moet ons later terugkom.

Dat hierdie verskeidenheid egter nie in alle gevalle as versoenbaar of as harmoniseerbare situasiebepaalde paradokse beskou en hanteer kan word nie (en dit is waaroor Schrage dit hierbo het), is reeds deur verskeie ondersoeke bewys. Hoewel daar twyfel en meningsverskil bestaan oor die aard en omvang van hierdie verskille, kan nie betwyfel word nie dat dit teologies eenvoudig onmoontlik is om al die verskillende teologieë in die Nuwe Testament (en ewe seer die Ou Testament) met mekaar te harmoniseer of op gelyke voet naas mekaar te handhaaf. En dit geld nie slegs sake wat beskou kan word as op-die-rand-liggend nie, maar ook sake wat as van sentrale belang in die teologie van die Nuwe Testament geag word (kyk hiervoor onder andere Käsemann 
1970; Braun 1971a; b; c; Dunn 1977; Joest 1970: 275; Köster \& Robinson 1971; Luz 1983; Pelser [1975]; 1986; 1987; en vgl Thüsing 1981). In die lig hiervan moet 'n grootskaalse harmoniseringspoging prinsipieel vanselfsprekend as onaanvaarbaar beskou word.

\section{SELEKSIE UIT EN VERENGING VAN DIE KANON IN TEOLOGIESE EN KERKLIKE PRAKTYK}

'n Grootskaalse harmoniseringspoging moet egter nie alleen as prinsipieel onaanvaarbaar beskou word nie; dit blyk ook 'n utopiese wensdenkery te wees. Die praktyk van die kerklike omgang met die kanon het naamlik deur die eeue heen, en veral sedert die Reformasie, oortuigende bewys gelewer dat so 'n harmonisering nooit werklik met sukses deurgevoer kon word nie. In hierdie verband moet daar volkome eenstemmigheid betuig word met die volgende stelling van Aland (1970: 154):

Es lässt sich nicht leugnen, dass der neutestamentlichen Kanon und zwar in der Vergangenheit wie in der Gegenwart, auch in den Kirchen mit absolut feststehenden Kanon, auch bei den Theologen aller Schulen und Richtungen, praktisch eine Verengung und Verkürzung erfährt (vgl ook Dunn 1977: 374; Barr 1980: 157; Du Toit sa: 187; Gamble 1985: 89).

Die bestaan van die verskillende kerke en sektariese strominge is inderdaad die uitvloeisel van so 'n verenging en verkorting van die kanon, sodat eweneens met Aland (1970: 155) saamgestem kan word wanneer hy sê: 'Gäbe es diese ... Verengung und Verkürzung des Kanons nicht ... gäbe es auch nicht verschiedene Konfessionen.' Hierdie toedrag van sake is natuurlik nie net die gevolg daarvan dat verskillende denominasies verskillende Bybelse konsepte as grondslag en riglyn neem vir leer en lewe nie, dit gebeur selfs waar bepaalde denominasies sogenaamd op dieselfde Bybelse grondslag bou en dan tog nog hierdie grondslag verskillend interpreteer. Uit die geskiedenis van die kerk blyk verder dat, afhangende van die tyd en die omstandighede, sekere Bybelse inhoude bo ander prominensie verkry het, en andersom, of dat dieselfde Bybelse inhoude dikwels in nuwe situasies anders geïnterpreteer of anders geaksentueer is as vroeër.

Waarop kom dit alles neer? Dit kom in die grond van die saak neer op 'n seleksie van bepaalde komponente van die kanon of die hoër skatting 
daarvan bo ander, of dit nou die een korpus of korpusse bo ander is of dele van 'n korpus bo ander dele daarvan. Of daar geselekteer word soos deur Marsion of Luther en of daar slegs aksentuerings plaasvind, feit is dat daar geselekteer word en derhalwe geopereer word met ' $n$ kanon in die kanon. Hoewel hierdie seleksie in sekere gevalle willekeurig plaasvind, kan ons dit nie ten opsigte van alle gevalle beweer nie. Nietemin moet dit aan die een kant toegeskryf word aan hermeneutiese vertrekpunte en vooronderstellings waarvan daar in die verskillende teologiese tradisies of denominasies uitgegaan word en die oortuiging by diesulkes dat hulle interpretasie en implimentering van die kanon net soveel reg het as die van ander. Maar dit is nie die enigste rede nie. Dit moet naamlik aan die ander kant ook daaraan toegeskryf word dat die Bybel homself leen vir hierdie pluralistiese aanwending.

\section{DIE KANON STIMULEER SELF DIE SELEKSIE EN BEGROND DIE PLURALITEIT}

Die bestaan van hierdie pluraliteit kan derhalwe nie slegs toegeskryf word aan uiteenlopende vooronderstellings of aan die histories-kritiese omgang met die kanon nie. Die historiese kritiek het alleen blootgelê wat daar in die Bybel self van sy ontstaan af aanwesig is. 'n Mens kom eenvoudig, minstens wat die Nuwe Testament betref, nie by die veelgesiteerde stelling van Käsemann (1970: 151) verby dat die NuweTestamentiese kanon as sodanig nie die eenheid van die kerk nie, maar die veelheid van die denominasies (Konfessionen) begrond. En voeg hierby die volgende opmerking van Dunn (1977: 377): 'To recognize the canon of the NT is to affirm the diversity of Christianity.' Die Nuwe Testament, en so ook die Ou Testament, is dus minstens ewe veel verantwoordelik vir hierdie seleksie en hierdie verskil in interpretasie, al is dit ook waar dat dit vanuit verskillende hermeneutiese vooronderstellings en teologiese voorkeure gemaak word. Dit is soos Barr (1980: 157) tereg opmerk:

Thus the need for priorities and preferences is not only something imposed upon the Bible by ecclesiastical, theological and academic tradition; these traditions have imposed it because the biblical material itself invites and requires it. 


\section{WAARAAN IS HIERDIE VERSKEIDENHEID EN UITEENLOPENDHEID TOE TE SKRYF?}

Waaraan is hierdie 'Variabilität' en in ' $n$ aantal gevalle 'erhebliche Spannungen' en in nog ander selfs 'unvereinbare theologische Gegensätze' (Käsemann 1970: 128) in die Nuwe Testament toe te skryf? Dit is in die eerste plek toe te skryf aan wat ons reeds in die Nuwe Testament aantref as hermeneutiese pogings tot verstaan van die Jesus-saak, of dan die Jesus-gebeure, en wat geglo is die implikasies daarvan is vir die kerk of die gelowige. Dit is verder die gevolg daarvan dat daar ook in sekere van hierdie verstaanspogings ontwikkelings plaasgevind het, sodat ' $n$ mens gekonfronteer word met die vraag watter ontwikkelingstadium geldend moet wees en watter nie. Dit is ten slotte die gevolg daarvan dat die kerk deur kanonvorming hierdie verskeidenheid in die kanon opgeneem het en daarmee fakties ook bepaalde teenstrydighede binne 'n formele omgrensing vasgevang het. Dit is soos Lönning (1972: 221 v) sê:

... die Kirche hat mit der Bewahrung und Auszeichnung einer Vielfalt von Gelegenheitschriften als die in Raum und Zeit allgemein gültige Norm ihrer Verkündigung ihre eigene permanente Krise - mit der permanente Krise ihrer behaupteten Norm bewahrt (my beklemtoning)

Soos die verskillende kerke of godsdienstige strominge vandag hulle posisie verdedig deur hulle op die kanon en op 'n 'legitieme' verstaan van die kanon te beroep, so het die verskillende kerklike kringe van die vroegste kerk, of daardie vroegste eksponente van die Jesus-saak, hulle natuurlik ook daarop beroep dat hulle hierdie saak legitiem verstaan en deurgegee het. Maar volgens watter norm kon hierdie eksponente hulle op so 'n juiste verstaan beroep? Dit is duidelik dat daar geen normatiewe vorm van Christendom in die eerste eeu bestaan het nie (so tereg Dunn 1977: 373). Bauer (1972) se ondersoek het voldoende bewys gelewer dat dit selfs ook nog nie die geval in die tweede eeu was nie. Daar was in die begin geen 'suiwer' vorm van Christendom wat werklik 'ortodoks' genoem kan word nie. 'In fact there was no uniform concept of orthodoxy at all - only different forms of Christianity competing for the loyalty of believers' (Dunn 1977: 3; vgl ook Meade 1986: 202, 205 v).

Die geskiedenis van, en die worsteling rondom die totstandkoming van die kanon gedurende die eerste vier eeue lewer ook bewys hiervan. Behalwe vir die kriterium van apostoliese getuienis, wat buitendien 'n 
problematiese saak was, was daar teologies geen ander algemeen geldende norm wat aangelê was of kon word nie. Dit mag waar wees dat die kriterium van regula veritatis of fidei later die beslissende geword het (kyk Ohlig 1972: 170), maar in feite het die daarstelling van hierdie kriterium op niks anders berus as wat beskou is as apostoliese oorlewering nie. Dit is verder opmerklik dat die kriterium van kanōn tēs alètheías wat die eerste keer by Ireneüs voorkom, deur hom op die geloof betrek word en nie op die Nuwe-Testamentiese oorlewering nie, hoewel ' $n$ mens waarskynlik met Aland (1970: $145 \mathrm{v}$ ) moet saamstem dat die kriterium in beginsel al vroeër en in 'n wyere sin moet gegeld het. Sonder om te beweer dat die opname van die verskillende geskrifte in die kanon op 'n lukraak wyse geskied het, kan 'n mens nogtans nie anders as om duidelik raak te sien dat daar nie altyd volkome duidelikheid oor normatiwiteit of kanonisiteit in die vroeë kerk bestaan het nie. Om hierdie rede is daar dan ook soveel verskillende en selfs teenstrydige teologiese standpunte in die kanon geïnkorporeer.

\section{DIE KANON IN DIE KANON}

Wat moet nou in die lig van die argumente hierbo ons hermeneutiese uitgangspunt wees by die hantering van die Nuwe Testament as kanon? Moet ons die saak maar laat soos dit is en dit aan elkeen oorlaat om met die verskeidenheid te maak soos hy goed dink en om uiteindelik te verkort of te selekteer soos hy wil? Almal sal seker saamstem dat willekeur nie die antwoord kan wees nie. Aan die ander kant lyk dit onvermydelik om die Nuwe Testament steeds bruikbaar vir Christene te laat bly, dat ons nie anders sal kan, as om met ' $n$ kanon in die kanon te werk nie. Ons moet steeds onthou dat dit maar altyd in die praktyk op een of ander wyse die geval was, en dit geld selfs vir die sogenaamde ortodokse benadering. Dunn (1977: 375) is daarom reg as hy sê: '. . . orthodoxy itself is based on a canon within the canon.'

Dit is egter opvallend en interessant om daarop te let dat selfs van die grootste hedendaagse kritici van die kanon hulle daarvan weerhou om die kanon fisies ò te vergroot ò te verklein. Bykans almal aanvaar dus, sommige wel met sekere voorbehoude, dat die kanon minstens formeel in sy huidige vorm behou moet word. Uit kritiese geledere hoor ons byvoorbeeld die volgende opmerking van Marxsen (1970: 246). 'Vergrössere ich sie, wird das Buch unhandlich. Verkleinere ich sie, verliere ich wertvolles Anschauungsmaterial gerade für die Kritik, die ich 
lernen muss.' Marxsen wil dus die kanon in sy huidige vorm behou, al is dit dan ook onder andere vir die doeleinde van noodsaaklike kritiek.

Hierdie relatiewe vrede wat die kritici met die formele kanon het, berus natuurlik daarop dat daar ' $n$ onderskeid gemaak word tussen die formele en die materiële of faktiese kanon. Dit behels dat nie die formele lys van geskrifte as kanoniek of normatief beskou word nie, maar wel die saak wat daarin vervat is. Dit is hierdie saak wat dan uiteindelik van deurslaggewende belang is, en in so 'n geval het ons natuurlik basies te doen met die keuse vir' $n$ kanon in die kanon. Maar soos die meeste van ons weet, kan hierdie kanon-in-die-kanon-idee verskillende gestaltes aanneem.

\subsection{Die verskillende gestaltes van die kanon in die kanon}

As eerste gestalte kan beskou word ' $n$ werkwyse soos die van Luther wat, hoewel hy Jakobus, Judas, Hebreërs en Openbaring in sy Nuwe Testament afgedruk het, dit daarin opgeneem het as ' $n$ soort aanhangsel sonder numering of bladsygetalle. Sy 'Sachkritik' volgens sy 'Christum treiben' kriterium het dus gelei tot 'n fisiese daarstelling van 'n kanon in die kanon deur die verkorting of verenging daarvan.

As tweede gestalte kan beskou word die benadering waarvolgens die hele lys fakties as kanon aanvaar word, maar geoordeel word dat kanonisiteit in konsentriese sirkels rondom 'n sentrum funksioneer. So beweeg die kanonisiteit vanaf 'n periferie van minder sentrale normatiwiteit na 'n sentrum van sentrale normatiwiteit. Berkhof (1979: 90) onderskei 'n viertal hiërargiese sirkels of vlakke, terwyl Barrett (1983: 18) verkies om hierdie beweging as 'n spiraal voor te stel. Laasgenoemde beklemtoon egter dat met die sentrum nie bedoel word dat die kanoniese gesag daarvan hoër is as dié van die gedeeltes wat op die periferie lê nie, aangesien daar volgens hom nie grade van kanonisiteit kan wees nie. Wanneer Barrett dus van die 'sentrum van die Nuwe Testament' praat, bedoel hy daarmee '... some part or aspect of it which expresses the content of the whole with special clarity, force or precision' (Barrett 1983: 18).

'n Standpunt soos hierdie lyk natuurlik op die oog af baie aanloklik en ortodoks en gee die indruk dat die kanon in sy geheel tog gehandhaaf word. So eenvoudig en verdienstelik as wat dit mag lyk, is die saak egter nie. 'n Mens kan nie anders as om met Barr (1980: 160) saam te stem dat dit ook maar neerkom op ' $n$ kanon in die kanon en dat hier ook maar 'n seleksie plaasvind nie. 
As derde gestalte kan onderskei word die werkwyse waarvolgens gewoon gesoek word na die kanon in die kanon in terme van dit wat as die 'Mitte' daarvan geïdentifiseer word, met in sekere gevalle die uitsluiting van dit wat nie as behorende tot hierdie 'Mitte' beskou kan word nie. Vir sommige, soos byvoorbeeld Kümmel (1970: 96) en Aland (1970: 155) loop hierdie 'Mitte' deur 'den Kanon mitten hindurch' (kyk ook Lohse 1982: 246). Vir ander is dit geleë in die drie 'groot blokke' van die Nuwe Testament, te wete die Jesusverkondiging, Paulus en die Johannesevangelie (so bv Braun 1971b: 320; vgl ook Barrett 1983: 10; Fuller 1982: 199; Stuhlmacher 1975: $177 \mathrm{v}$, laasgenoemde praat van die 'Kernbestand' in die vier evangelies en Paulus, waaronder Paulus dan die 'Schlüsselstellung' beklee), terwyl nog ander dit slegs in die 'Pauliniese evangelie' vind (so bv Schulz 1976: 429). Dit is duidelik dat in laasgenoemde twee benaderings dit die latere geskrifte, oftewel die geskrifte verteenwoordigend van die sogenaamde 'Frühkatholizismus', is wat nie in aanmerking kom as draers van die 'Sachmitte' van die Nuwe Testament nie (kyk bv Braun 1971c: 322). Op ietwat radikale wyse stel Schulz (1976: 430) in hierdie verband:

Der neutestamentliche Kanon enthält nicht nur das paulinische Evangelium, sondern gleichzeitig seine Verstehensgeschichte, die in Wirklickheit eine Geschichte der Missverständnisse, Fehlentwicklungen und Irrwege ist.

'n Standpunt soos hierdie van Schulz verskil duidelik nie veel van die van Luther nie, aangesien dit prakties ook maar neerkom op die fisiese uitskakeling van sekere geskrifte uit die kanon.

\subsection{Waaruit bestaan hierdie 'Sachmitte' in die kanon?}

Maar indien daar wel van die idee van ' $n$ kanon in die kanon uitgegaan moet word, wat kan dan beskou word as die 'Sachmitte' wat as 'sachkritische' kriterium aangewend moet word? Dit is duidelik dat ook op hierdie vraag die antwoorde uiteenlopend is, soos deur die volgende geillustreer word. Vir sommige is dit Jesus, nader gekwalifiseer as die 'Sache Jesu' (bv Marxsen 1967: 64; 1970: 242) of die 'Christusoffenbarung' (Kümmel 1970: 94) of 'Jesus-the-man-now-exalted' (Dunn 1977: 376) of the 'Stimme Christi' (Diem 1970: 173). Vir ander weer is dit die iustificatio impii (bv Käsemann 1970: 405; Schulz 1976: 423; Schrage 1976: 440). Vir Barrett (1983: 16) is dit solus Christus èn sola fide, vir Fuller 
(1982: 189) die vraag of ' $n$ geskrif of ' $n$ teologiese ontwikkelingslyn beantwoord aan die 'directionality' wat veral deur Paulus, Markus en Johannes aangedui is in verband met die Christusgebeure, terwyl dit vir Braun (1971b: 321) '. . . der radikal geforderte und in Frage gestellte als der im Jesus-geschehen radikal gehaltene Mensch' is.

Dit is duidelik dat wat die identifisering en aanwending van hierdie kanonkriteria betref, daar 'n sirkelbeweging plaasvind: Die kriterium word uit die Nuwe Testament self ontleen en dan word die Nuwe Testament krities daaraan getoets. Volgens Braun (1971b: 322) is hierdie sirkelbeweging onvermydelik juis omdat die Nuwe Testament die genoemde teenstrydighede in homself omdra. So paradoksaal as wat dit mag klink: hierdie benadering respekteer die kanon op sy grondigste en op die gepaste wyse wanneer dit daarin as kanon, as ' $n$ formele entiteit, slegs relatief geinteresseerd is (Braun 1971b: 323).

\subsection{Hoe kom ons by die 'Sachmitte' uit?}

Wanneer gevra word hoe ons by hierdie 'Sachmitte' uitkom, word eweneens verskillende antwoorde gegee. Die kwessie is veral problematies met betrekking tot die Jesus-saak. Na watter Jesus moet ons soek en hoe kom ons by Hom uit? Die feit dat daar verskillende interpretasies van die Jesusgebeure in die Nuwe Testament is, maak die saak uiters gekompliseerd. Ons het dieselfde probleem wanneer ons soos Braun die 'Sachmitte' in die Nuwe-Testamentiese antropologie as sogenaamde konstante sou soek. Watter antropologie van die Nuwe Testament moet as kriterium dien? Streng gesproke moet Van den Hoogen (1986: 48ki gelyk gegee word as hy sê dat om 'n sentrale leerstuk in die Bybel te vind, literêr alreeds as 'n onmoontlikheid beskou moet word.

Dit lyk egter onvermydelik dat 'n bepaalde keuse of keuses gemaak sal word, en inderdaad gemaak word, en dat hierdie keuses, soos reeds gesê, nie alleen deur die Nuwe Testament bepaal word nie, maar ook deur die hermeneutiese vooronderstellings en kenteorieë van die teoloog of teologiese groepering wat hom met die kanon besig hou. Hierdie keuses sal ook wisseł na mate daar 'n nuwe 'Wirklichkeitsverständnis' (Luz 1983: 146) na vore tree, ontwikkeling in teologiese denke plaasvind en die situasies waarin die Nuwe Testament geïnterpreteer en verkondig moet word, verander. Daar kan streng gesproke nooit 'n absolute kriterium wees of slegs één hermeneutiese sleutel wat vir eens en vir altyd geld nie. 
Dit beteken aan die ander kant nie dat elkeen maar willekeurig sy eie kanon daarop kan nabou of dat die laaste grond vir kanonisiteit uiteindelik, soos Diem (1970: 167) meen, daarin lê 'dass sie sich predigen lässt' nie. Hoewel 'n mens Diem moet toegee dat 'n teks wat hom nie laat preek nie, kwalik normatief kan wees, loop so 'n standpunt die gevaar om die resepsie van die teks te eensydig die bepalende faktor vir kanonisiteit te maak. Hiermee word nie beweer dat Diem so 'n eensydigheid voorstaan nie, inteendeel. Die gevaar hiervan is egter wesenlik. Hierby moet egter ook weer gewys word op die onontkenbare feit dat daar geen norm voorafgaande aan die interpretasie van die Bybel is, wat vir die teoloog as absolute riglyn kan dien nie. Barr (1980: 162 ) is reg wanneer hy sê dat in die moderne teologiese opset die proses van seleksie nie onder 'n voorskrywende outoriteit staan nie, 'but under the criticism of a discussion which looks at what comes out of it.' Hy beskou dan ook die proses van vrye selektering en ordening van die materiaal van die kanon as deel van die oorspronklikheid en kreatiwiteit van 'n groot teologie (Barr 1980: 162).

\subsection{Hoe kontroleer ons hierdie soeke?}

Wat Barr hierbo gesê het met betrekking tot die kontrole wat uitgeoefen word deur die kritiek wat deur wetenskaplike diskussie gelewer word, is vir ons onderwerp van die uiterste belang. Dit kom basies op dieselfde neer as wat Schroedel (1986) in verband met die interpretasie van tekste sê. Elke leser maak by die lees van 'n teks 'n subjektiewe seleksie van wat hy as belangrik beskou en dit gebeur in die meeste gevalle intuitief. Maar dit wat hy so intuitief uit die teks verkry het, kan nie as kriterium van waarheid geld nie. Om dit wat hy uit die teks verstaan, met ' $n$ ander te kan deel en vir ' $n$ ander aanvaarbaar te maak, moet hy bereid wees om sy verstaan van die teks te onderwerp aan intersubjektiewe kontrole. As individu kan die leser slegs homself tevrede stel met sy spontane verstaan van die teks. As sosiale wese moet hy sy verstaan daarvan egter kan fundeer in intersubjektiewe dialoog met iemand anders. Sy verstaan kan dus alleen meedeelbaar wees aan 'n ander, as die ander dit werklik met hom kan deel (Kyk Schroedel 1986: $130 \mathrm{v}$ ). Dit geld soveel te meer vir die Bybelleser, en in die besonder vir ' $n$ teoloog in sy omgang met die teks en daarom met die kanon.

Hierdie vryheid van seleksie, maar tegelykertyd die onderworpenheid aan die kritiek van teologiese diskussie, is prakties wat in die 
geskiedenis van kerk en teologie aan die orde was sedert die historiese kritiek in die omgang met die kanon op gang gekom het. Die Reformasie het hiervoor die baan gebreek en die Aufklärung, die hermeneutiese, ken- en teksteoretiese ontwikkelinge sedertdien, sowel as die insig in verband met die rol wat die sosiale konteks van die leser by interpretasie speel, het hierdie proses onomkeerbaar gemaak. Daar is meer as ooit tevore teologies gereflekteer en geglo op die basis van 'n kanon in die kanon, sonder dat die lys, in die oorgrote meerderheid van gevalle, formeel verklein of vergroot is. Natuurlik het dit, soos reeds gesê, minstens in nie-Roomse kringe gelei tot 'n veelvoud van denominasies en godsdienstige strominge. Moet dit as ' $n$ jammerlike of sondige verskeurdheid van die kerk gesien word of eerder as ' $n$ logiese uitvloeisel van die Bybelse verskeidenheid? Dit blyk onteenseglik te wees dat toe die Bybel eenmaal bevry is van die Roomse uitleginstansie, die deur geopen is vir verskillende, dikwels uiteenlopende en soms helaas ook onhoudbare teologiese posisies. Hoe haalbaar of verdedigbaar hierdie teologiese posisies is, is moeilik om te sê, maar dat die Bybel in sy verskeidenheid vir baie daarvan in mindere of meerdere mate akkommodasie bied, is seker. Hierdie veelvoud van teologieë wat hulle almal op die Bybel beroep, kan daarom nie sonder meer afgewys of negatief waardeer word nie. Dit hou minstens ook die voordeel in van voortgaande teologiese debat, kritiek en selfkritiek, wedersydse bevrugting en gevolglike teologiese kreatiwiteit en ontwikkeling.

\section{DIE PAD VORENTOE}

Intussen is die Bybel as kanon nie vir sy spreke afhanklik van hierdie teologieë nie, maar spreek dit telkens hierdie teologieë aan in die hermeneutiese sirkelbeweging tussen teks en eksegeet. Êrens in hierdie wisselwerking, in hierdie lewende relasie tussen teks en leser of eksegeet, genereer die teks die betekenis wat tot verstaan, dit wil sê tot selfverstaan, bring. Wat die teks te sê sal hê, kan nie voorgeskryf of vooraf bepaal word nie. Dit vind alleen plaas in verantwoordelike omgaan met die teks en in verstanende ontmoeting met die teks. In kerklike kring kan hierdie ontmoeting met die teks egter nooit slegs 'n private aangeleentheid wees of bly nie. Dit kan nie bly vassteek by persoonlike ervarings met die teks nie. Dit moet aan ander gekommunikeer kan word, en op so 'n wyse dat dit gemeenskaplik gedeel kan word. Indien daar enigsins van kerklike teologie sprake wil of moet 
wees en indien daar ' $n$ teologiese basis moet wees waarop gelowige eksistensie moet berus en moontlik moet wees, moet daar binne ' $n$ bepaalde kerklike kring minstens tot op sekere hoogte 'n 'deelbare teologie' wees. Vanweë die openheid van die kanon, wat geleë is in sy verskeidenheid en meerduidigheid, en vanweë die feit van die verskeidenheid van indiwiduele resepsie en verstaan, sal daar egter nooit ' $n$ teologie kan bestaan wat in sy geheel deur die hele Christelike kerk gedeel sal kan word nie. Tog was dit in die verlede so en is dit tans nog die geval dat ' $n$ bepaalde teologie in bepaalde kerklike kringe gedeel word en dat kerklike kringe onderling tot op sekere hoogte bepaalde fasette van ' $n$ teologie met mekaar deel. Die graad van deelbaarheid verskil natuurlik ook altyd van denominasie tot denominasie of van teologiese kring tot teologiese kring. In die gevalle waar dogmatisme voorskriftelik oor teologiebeoefening is en dit sodoende inhibeer, is die graad van deelbaarheid groter, maar teen 'n prys. In die gevalle waar ruimte gelaat word vir vryheid in diskussie en derhalwe vir teologiese kreatiwiteit, is die graad van deelbaarheid kleiner, maar die gedeeldte is gewoonlik meer verantwoord. Dit geld nie alleen die teologie in die algemeen nie, maar spesifiek ook die omgang met die kanon.

Sedert betreklik vroeë tye het die kerk se verkondiging en leer, breedweg gesien en met variasies, tradisioneel gesentreer rondom die vier evangelies en Paulus en rondom elemente uit die ander geskrifte wat as in ooreenstemming hiermee beskou is. Die kerk het op hierdie geskrifte gekonsentreer omdat hy van oortuiging was dat die handeling van God deur Jesus Christus, en wat dit impliseer, die duidelikste (normatiefste) in hierdie kanon in die kanon verkondig word. Daar is nie rede om te glo dat die situasie in die voorsienbare of selfs verre toekoms sal verander nie. Daar is met ander woorde nie rede om te glo dat die kerk of Kerke nie sal voortgaan om met 'n kanon in die kanon te werk nie. Verskillende denominasies sal ook voortgaan om hulle bestaan en voortbestaan deur húlle besondere kanon in die kanon te probeer legitimeer of akkommodasie in húlle deel van die kanon te probeer vind. Dit is, soos reeds opgemerk, deur al die eeue heen in die kerk gedoen en dit word steeds gedoen sonder dat eksplisiet gesê of erken word dat met ' $n$ kanon in die kanon gewerk word. Ons sien slegs die resultate of simptome daarvan.

Dit lyk op die oog af na 'n verwarrende prentjie en na 'n hopelose disparaatheid. En indien wel, hoe verhelp ons dit, en kan ons dit verhelp? Dit lyk nie of ons veel daaraan kan doen nie, veral nie in die lig van die feit dat die formele kanon dit self onmoontlik maak nie, 
tensy al die Kerke natuurlik tot beide 'n formele seleksie èn interpretasie van die kanon kan ooreenkom. Maar ook dit, het ons reeds gesien, moet as utopies en as ' $n$ illusie afgewys word. Hierbenewens moet dit ook tot op minstens sekere hoogte as onwenslik beskou word. Wat naamlik vandag formeel geselekteer word, mag môre op die rand te staan kom of laat vaar word, en andersom. Dit lyk dus nie of 'n uitgesproke en programmatiese formele selektering gerade en die antwoord is nie, hoewel toegegee moet word dat dit wil lyk of sekere gedeeltes van die kanon nooit werklik 'n teologiese rol sal vervul nie.

In die lig van hierdie toedrag van sake blyk die aanvaarbaarste antwoord, beide inter- en intrakerklik, steeds die voortgaande teologisering en teologiese debat oor die kanon oftewel die kanon in die kanon te wees. 'n Mens moet natuurlik erken dat in 'n oop of vry kanonbenadering die deur vir willekeur of eensydigheid wawyd oopstaan. Maar die moontlikheid om inderdaad deur hierdie deur te beweeg, is nie naastenby so sterk as wat dit op die oog af mag voorkom nie. Dit word op sy doeltreffendste aan bande gelê deur die kontrole wat juis uit 'n oop en vrye benadering tot die kanon spruit, naamlik die kontrole van toetsing deur openhartige teologiese debat met werklike diepgang. Ons het nie ' $n$ ander aanvaarbare opsie nie en daar is nie ' $n$ beter kontrole as hierdie nie.

Daar kan ook nie genoeg klem gelê word op die noodsaaklikheid van hierdie debat en die kontrolewaarde wat dit inhou nie. Maar dan moet die debat nie ter wille van kontrole gevoer word nie. Dit mag dus nie ketterjagtery of dwaalleeruitsnuffelry as motief hê nie. Dit moet gevoer word ter wille van die teologie en daarom ter wille van die kanon. Dit sal nie noodwendig ' $n$ Kerk van sy tradisionele teologie laat afsien nie, want elke teologiese en kerklike tradisie sal maar altyd sy eie voorkeure hê. Maar dit kan minstens by hom teologiese vernuwing of progressie teweegbring, of hom dwing en help om sy bestaande teologiese standpunte beter te verantwoord en duideliker te formuleer. ' $n$ Kunsmatige harmonisering of die afdwing van 'n geforseerde gelykstelling van die formele en die prinsipiële kanon of die gebruik van één hermeneutiese sleutel sal ons nêrens bring nie. Dit sal die teologie dood maak, soos so dikwels gebeur het, teologiese debatvoering en bevrugting beëindig en die verskeidenheid van die Bybel tot ' $n$ trefkraglose monotonie laat verskraal.

Intussen kan die kanon, en moet dit waarskynlik, bly soos dit is en minstens beskou word as voldoende vir 'leer' en lewe. Daar lê 'n onontkenbare waarheid opgesluit in Marxsen se standpunt dat ons die 
hele kanon nodig het om ons te help om die kanon in die kanon te onderskei. Dit kan aan die ander kant eensydigheid help voorkom:

... for although it (die kanon - GMMP) requires a reduction and specification of its meaning in order to exercise a nomative function, it nevertheless resists the absolutizing of any particular appropriation and so maintains the potentialities of interpretation against dogmatic foreclosures (Gamble 1985: 89).

Maar dan moet ons nie daarvoor terugdeins om, waar nodig, krities met die kanon om te gaan of selektiewe omgang daarmee te erken nie. Dit is minstens die eerlike weg om te volg. Dit is nie vir voortgaande teologiese debat en wedersydse teologiese bevrugting bevorderlik as ons deur mooiklinkende ortodokse uitsprake of belydenisse probeer voorgee wat ons nie doen nie of probeer verberg wat ons wel doen nie. Piëteit teenoor die kanon is gebiedend, maar dit word ' $n$ klug as dit ons daarvan weerhou om die kanon werklik ernstig en krities te benader en om die moed aan die dag te lê om ons oortuiging oor die saak uit te spreek. Die teologie en die kerk sal hulle sonder twyfel in ' $n$ beter posisie bevind wanneer hulle hulle in openheid deur die problematiek van die kanon laat aanspreek en nie die oë vir die werklikheid sluit nie. So ' $n$ openheid is nie alleen meer verantwoord nie, dit het ook ' $n$ beter kans om die gelowige eietyds in 'n eksistensiële ontmoeting met die saak (of sake) van die Bybel te laat tree. Wat hierdie saak, hierdie kanon in die kanon sal wees, sal telkens opnuut moet duidelik word na mate die kanon in elke situasie inspreek, en teologie en kerk gelei word om hierdie kanonieke spreke te onderskei. Dit gaan dus nie om die vind van 'n sentrale, onveranderlike leerstuk in die kanon nie, maar om die kritiese vraag wat die Bybel telkens aan die mens in sy situasie hier en nou stel (so tereg Van den Hoogen: 488).

Hierdie opstel word met hoë waardering en dankbaarheid opgedra aan professor BJ Engelbrecht wat as my dosent, promotor en jarelange vriend ' $n$ belangrike rol tot my vorming bygedra het en met sy veelsydigheid, verstandelike begaafdheid en teologiese insigte ' $n$ blywende indruk op my gemaak het. Ek doen dit in die vertroue dat dit sy statuur waardig sal wees.

\section{Literatuurverwysings}

ALAND, K [1962] 1970. Das Problem das neutestamentlichen Kanons, in Käsemann 1970: 134-158. 
BARR, J 1980. The Bible in the modern worla. London: SCM.

BARRETT, CK 1983. The centre of the New Testament and the canon, in Luz \& Weder: 1983: 15-21.

BAUER, WC [1934] 1972. Orthodoxy and heresy in earliest Christianity. London: SCM (NTLi.)

BERKHOF, H 1979. Christian faith: An introduction to the study of the faith. Transl by S Woudstra. Grand Rapids: Eerdmans.

BRAUN, H 1971. Gesammelte Studien zum Neuen Testament und seiner Umwelt. 3. Aufl. Tübingen: Mohr.

BRAUN, H [1957] 1971a. Der Sinn der neutestamentlichen Christologie, in Braun 1971: 243-282.

BRAUN, H [1960] 1971b. Hebt die heutige neutestamentlich-exegetische Forschung den Kanon auf?, in Braun 1971: 310-324.

BRAUN, H 1971c. Die Problematik einer Theologie des Neuen Testaments, in Braun 1971: 325-341.

CHILDS, BS 1984. The New Testament as canon: An introduction. Philadelphia: Fortress.

DIEM, H [1952] 1970. Das Problem des Schriftkanons, in Käsemann 1970: 159-174.

DUNN, JDG 1977. Unity and diversity in the New Testament: An inquiry into the character of earliest Christianity. London: SCM.

DU TOIT, AB s a. Kanoniek van die Nuwe Testament, in Roberts, JH \& Du Toit, AB, Inleiding tot die studie van die Nuwe Testament: Kanoniek van die Nuwe Testament, 83-294. Pretoria: NG Kerkboekhandel. (Handleiding by die Nuwe Testament, I).

FULLER, RH 1982. New Testament trajectories and Biblical authority, in Livingstone, EA (ed), Studia evangelica VII: Papers presented to the fifth international congress on Biblical studies held at Oxford, 1973, 189-199. Berlin: Akademie.

GAMBLE, HY 1985. The New Testament canon: Its making and meaning. Philadelphia: Fortress. (Guides to Biblical scholarship.)

JOEST, W [1966] 1970. Erwägungen zur kanonischen Bedeutung des Neuen Testaments, in Käsemann 1970: 258-281.

KÄSEMANN, E 1970 (Hrsg). Das Neue Testament als Kanon: Dokumentation und kritische Analyse zu gegenwärtigen Diskussion. Göttingen: Vandenhoeck.

KÄSEMANN, E 1970. Begründet der neutestamentliche Kanon die Einheit der Kirche?, in Käsemann 1970. 124-133.

KÖSTER, H \& ROBINSON, JM 1971. Entwicklungslinien durch die Welt des frühen Christentums. Tübingen: Mohr.

KÜMMEL, WG [1965] 1970. Notwendigkeit und Grenze des neutestamentlichen Kanons, in Käsemann 1970: 62-97.

LOHSE, E 1982. Die Vielfalt des Neuen Testaments: Exegetische Studien zur Theologie des Neuen Testaments II. Göttingen: Vandenhoeck.

LÖNNING, I 1972. 'Kanon im Kanon': Zum dogmatischen Grundlagenproblem des neutestamentlichen Kanons. Oslo: Universitets Forlaget.

LUZ, U 1983. Einheit und Vielfalt neutestamentlicher Theologien, in Luz \& Weder 1983: $142-161$.

LUZ, U \& WEDER, H 1983 (Hrsg). Die Mitte des Neuen Testaments: Einheit und Vielfalt neutestamentlicher Theologie. Festschrift für Eduard Schweizer zum 70. Geburtstag. Göttingen: Vandenhoeck.

MARXSEN, W 1967. Das Neue Testament als Buch der Kirche. 2 Aufl. Gütersloh: Mohn.

MARXSEN, W [1960] 1970. Das Problem des neutestamentlichen Kanons aus der Sicht des Exegeten, in Käsemann 1970: 233-246.

MEADE, DG 1986. Pseudonymity and canon: An investigation into the relationship of authorship and authority in Jewish and earliest Christian tradition. Tübingen: Mohr. (WUNT.) 
NEILL, S 1966. The interpretation of the New Testament 1861-1961. London: Oxford University Press. (OPB).

OHLIG, K-H 1972. The theologische Begründung des neutestamentlichen Kanons in der alten Kirche. Düsseldorf: Patmos.

PELSER, GMM [1975]. Die nagmaal by Markus en Paulus: 'n Vergelykende studie. HTS 30, 138-149.

PELSER, GMM 1986. Resurrection and eschatology in Paul's letters. Neotestamentica 20, 36-45.

PELSER, GMM 1987. Temaprediking uit die Nuwe Testament. HTS 43, 556-565.

SANDERS, JA 1984. Canon and community: A guide to canonical criticism. Philadelphia: Fortress.

SCHRAGE, W 1976. Die Frage nach der Mitte und dem Kanon im Kanon des Neuen Testaments in der neueren Diskussion, in Friedrich, J, Pohlmann, W \& Stuhlmacher, P (Hrsg), Rechtfertigung: Festschrift für Ermst Käsemann zum 70. Geburtstag, 415-442. Tübingen: Mohr.

SCHROEDEL, JH 1986. Text, Leser und Metode: 3 Grund- und Arbeitsfragen der Schriftauslegung Buki 41, 125-135.

SCHULZ, S 1976. Die Mitte der Schrift: Der Frühkatholizismus im Neuen Testament als Herausforderung an den Protestantismus. Stuttgart: Kreuz.

STUHLMACHER, P 1975. Evangelische Schriftauslegung heute, in Schriftauslegung auf dem Wege zur biblischen Theologie, 167-183. Gottingen: Vandenhoeck.

THÜSING, W 1981. Die neutestamentlichen Theologien und Jesus Christus I: Kriterien Aufgrund der Rückfrage nach Jesus und des Glaubens an seine Auferweckung. Düsseldorf: Patmos.

VAN DEN HOOGEN, T 1986. Schrift lezen: Omtrent het selektief omgaan met de Bijbel. Praktische Theologie 13, 477-502. 